\title{
The transverse strength of acrylic resin after Coleus amboinicus, Lour extract solution immersion
}

\author{
Devi Rianti \\ Department of Dental Material and Technology \\ Faculty of Dentistry Airlangga University \\ Surabaya - Indonesia
}

\begin{abstract}
A laboratoric experimental study was conducted on the transverse strength of acrylic resin after Coleus amboinicus, Lour extract solution immersion. The aim of this study is to know the difference of acrylic resin transverse strengths caused by immersion time variations in a concentrate solution. The study was carried out on unpolished acrylic resin plates with $65 \times 10 \times 2,5 \mathrm{~mm}$ dimension; solution with 15\% Coleus amboinicus, Lour extract, and 30, 60, 90 days immersion times to measure the transverse strength and sterilized aquadest was used as control. Acrylic resin plates transverse strength was measured using Autograph AG-10 TE. The data was analyzed using One-Way Anova and LSD with 5\% degree of significance. The result showed that longer immersion time will decrease the transverse strength of the acrylic resin plates. After 90 days immersion time, the transverse strength decrease is still above the recommended standard transverse strength.
\end{abstract}

Key words: Coleus amboinicus, Lour, Candida albicans, transverse strength, denture cleanser, resin acrylic

Correspondence: Devi Rianti, c/o: Bagian Ilmu Material dan Teknologi Kedokteran Gigi, Fakultas Kedokteran Gigi Universitas Airlangga. Jln. Mayjend. Prof. Dr. Moestopo 47 Surabaya 60132, Indonesia.

\section{INTRODUCTION}

Up to now acrylic resin is still used as denture base due to the advantage of having good physical and esthetic character, small dimension change and being easily repaired. In addition to the advantage, acrylic resin also has the disadvantage such as: residual monomer, porous, water absorption and less resistant to abrasion. ${ }^{1,2}$

Acrylic resin in oral cavity is covered by saliva with high protein content as a result pellicle formation occurs. This pellicle is able in having adherence to microorganism such as Candida albicans. ${ }^{3}$ Pellicle, in two-hour period, would change into plaque which consist of a cluster of microorganism, glycoprotein matrix as well as polysaccharide which adheres to the teeth surface. The process of plaque formation is similar to the process occurs in denture surface. ${ }^{4}$

Stomatitis on a patient wearing removable denture is called denture stomatitis in which the prevalence is quite high in Indonesia and characterized by the present of Candida albicans cluster. ${ }^{5}$ The statement is supported by a study which reported that the present of Candida albicans detected in $64 \%$ of 50 patients using acrylic resin denture base. ${ }^{6}$ Some researchers stated that the character of denture material, pellicle as well as Candida albicans give the most contribution to the occurrence of denture stomatitis. ${ }^{3,7}$

Denture stomatitis can be prevented by taking care, cleansing and taking off the denture at night. ${ }^{8}$ To clean the denture can be done in two-ways by either mechanically or chemically. Mechanical cleaning can be done by using tooth brush or ultra sonic device, meanwhile chemical cleaning can be done by immersing the denture in cleansing solution in 15 minutes, 30 minutes, one hour or the whole night depends on the cleansing material being used. ${ }^{9}$ Furthermore, other researcher stated with fungicide effect should be done minimally 30 minutes and more effectively done in two hours. ${ }^{10}$

Denture cleanser which is available in the market is frequently imported but currently the Indonesian government is actively promoting traditional herb as an alternative medication, and as a matter of fact, Indonesia is really reach or herbal plant. Therefore, based on national health system emphasizing on effective and efficient traditional medication, in which it should be guided and done through / for experiment and scientific research on herbal plant.

One of family herbal medicines which is easily planted and grown in the garden is daun jinten with the Latin name: Coleus amboinicus, Lour or Plectranthi amboinicus folium. The plant is efficacious medication for stomatitis and fungicidal. ${ }^{11}$ It has kalium content and essential oil containing carvacrol, isopropyl - o - cresol, phenol and cineol. Additionally explained that $120 \mathrm{~kg}$ of fresh Coleus amboinicus, Lour could obtain $25 \mathrm{ml}$ of essential oil. This is equivalent to $0.2 \%$ of essential oil consisting of phenol derivation that is isopropyl-o-cresol with high antiseptic capability. ${ }^{12}$ The previous study reported that $15 \%$ concentration of extract Coleus amboinicus, Lour effectively killed Candida albicans in acrylic resin after a two-hour of immersion time. ${ }^{13}$

Cineol chemical substance has anti microbial capability towards Candida albicans, Trichiphyton metagrophytes 
and Cryptococcus neoformans. ${ }^{14}$ Phenol and cresol could kill vegetative cell, fungi and spore configuring bacteria by creating protein denaturizing and decreasing surface strain, so bacterial permeability would increase. ${ }^{15}$ Meanwhile according to Merck index ${ }^{16}$ carvacrol has fungicidal. In addition to its fungicidal, phenol which is one of the essential oil element, in case of having contact to acrylic resin, it would cause chemical damage to the surface of acrylic plate. ${ }^{17}$

Coleus amboinicus, Lour had fungicidal and phenol content which could destroy acrylic resin. Other researcher stated that acrylic resin immersion in cleansing solution or anti bacterial solution could change the basic physical and mechanical character of acrylic resin denture such as decreasing the transverse strength. ${ }^{18}$ Based on the above analysis, the problem arose whether there might be differences in acrylic resin transverse strength caused by various duration of immersion in extract solution of Coleus amboinicus, Lour. How long is the effective immersion time in extract solution of Coleus amboinicus, Lour without decreasing the transverse strength of acrylic resin.

The purpose of the study was to know the transverse strengths of acrylic resin caused by various duration of immersion in extract solution of Coleus amboinicus, Lour and to determine the effective duration of immersion without decreasing the transverse strength.

The advantage of the study outcome would contribute scientific information on the effective duration of immersion of acrylic resin in extract solution of Coleus amboinicus, Lour without decreasing the transverse strength. This shall be used as the basic determination to the use of this solution as an alternative of cleansing material for denture treatment.

\section{MATERIALS AND METHODS}

Experimental laboratory study was conducted with the subject of $(65 \times 10 \times 2.5) \mathrm{mm}$ unpolished acrylic resin plate, using free variable of which the immersing period were 30,60, and 90 days, the variable depended on the strength of transverse acrylic resin. Control variable were: The type of acrylic resin, method of making samples, sample size, polymerization method, similarity of soil for planting Coleus amboinicus, Lour, harvest time, drying time, method of making Coleus amboinicus, Lour extract using ethanol solution, concentration of extract solution, device and method of measuring transverse strength.

The study was initiated by making the samples as well as preparing extract solution of Coleus amboinicus, Lour, diluting the extract of solution Coleus amboinicus, Lour, preparing profile chromatogram with thin layer extract as done by former researchers to know the active content in the extract, and also the transverse strength test. ${ }^{13}$ The extract solution of Coleus amboinicus, Lour preparation was done in the Fitochemical Laboratory of Faculty of Pharmacy of Airlangga University. The extract was prepared as follows:
3-4 months aged of Coleus amboinicus, Lour leaves freshly cropped at 07.00 a.m. at the Traditional Medicine Research Center experimental plantation, then washed and dried in a room with $24^{\circ} \mathrm{C}$ of temperature. After being dried, they were grinded. The powder weighted as of 1000 gram then solved in $3000 \mathrm{ml}$ of ethanol for 72 hours and afterwards it was filtered using a Buchner quill. The filtrated solution evaporated using vacuum evaporator for 5 hours, and it yielded 100 grams of pure Coleus amboinicus, Lour extract. ${ }^{19}$ Afterwards 1.5 grams of the extract solved in 10 $\mathrm{ml}$ of sterile aquadest and vibrated in an ultrasonic vibrator for 15 minutes to obtain a $15 \%$ concentrated solution.

The transverse strength test was carried out by using autograph A6-10 TE with cross head speed 1/10 mm/sec. The distance between two supporting parts was $50 \mathrm{~mm} .{ }^{20} \mathrm{At}$ the beginning all of the acrylic resin plates were immersed in aquadest for 48 hours. ${ }^{21,22}$ Then they were immersed in Coleus amboinicus, Lour extract solution and classified into 3 groups based on the duration of immersion i.e. 30, 60 , and 90 days. Replacement of immersion solution was done in every 24 hours. All immersion processes were performed in room temperature $27 \pm 1^{\circ} \mathrm{C}$. Immersion for control is specially done in aquadest. After immersions performed in individual period, the acrylic resin plates were cleansed with aquadest, dried, and finally transverse strength tested. The result of the test was calculated based on the following formula: 18

$$
S=\frac{3 P}{2 b d^{2}}
$$

S: transverse strength, b: specimen width (mm), I: support distance $(\mathrm{mm})$,

d: specimen thickness, P: load weight $(\mathrm{N})$

The result of measurement was tabulated according to the individual group, followed by statistical test by using One-Way ANOVA with $=0,05$. If the outcome was significantly different, the test would be continued using LSD test.

\section{RESULT}

After the acrylic resin plates immersion processes in $15 \%$ concentration of extract solution of Coleus amboinicus, Lour in the period of 30,60, 90 days, and using aquadest as control were completed, the transverse strength was measured by using Autograph AG-10 TE. The outcome of this is shown on table 1 .

Prior to do the parametric test, a Kolmogorov-Smirnof test as a normality test was performed to get the significance difference. The result of the three treated group as well as the control showed normal distribution $(p>0.005)$ and followed by comparation test for the four groups and control through One-Way ANOVA test. The result of One-Way ANOVA test showed significant difference among the 
Table 1. Mean and standard deviation of transverse strength of acrylic resin after immersion in $15 \%$ extract solution of Coleus amboinicus, Lour (Mpa)

\begin{tabular}{|c|c|c|c|c|c|c|}
\hline \multirow{3}{*}{ Concenterion } & \multicolumn{6}{|c|}{ Peind } \\
\hline & \multicolumn{2}{|c|}{30 ths } & \multicolumn{2}{|c|}{$601 \mathrm{H}=$} & \multicolumn{2}{|c|}{ 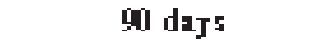 } \\
\hline & $\bar{x}$ & 95 & $\bar{x}$ & 9[ & $\bar{x}$ & 9[ \\
\hline Aquader & 1021 & 6.19 & $\operatorname{ggg} 58$ & 583 & 101.59 & 6.01 \\
\hline 154 & ㅁ․ 65 & 3.87 & 8357 & 361 & $72 \pi$ & 6.23 \\
\hline
\end{tabular}

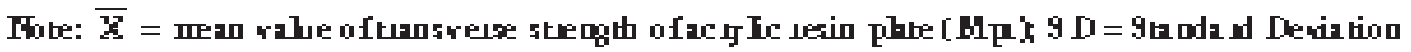

Table 2. Least Significant Difference test of transverse strength of acrylic resin plates immersed in extract solution of Coleus amboinicus, Lour

\begin{tabular}{|c|c|c|c|c|c|c|}
\hline 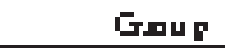 & $31 \mathrm{deg}$ & Glu dege & ب!̣ de & 도 & 미 & 므 \\
\hline 도 & 9 & 9 & 9 & IE & IB & - \\
\hline 머 & 9 & 3 & 3 & $\mathbf{I B}$ & - & \\
\hline 도 & 9 & 9 & 3 & - & & \\
\hline प̣̂ des & 9 & 9 & - & & & \\
\hline 6) desr & 9 & - & & & & \\
\hline Jli der & - & & & & & \\
\hline
\end{tabular}

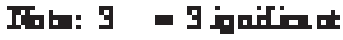

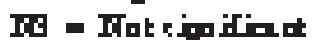

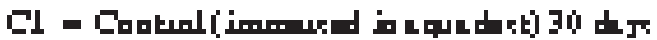

treated groups with $\mathrm{p}=0.001(\mathrm{p}<0.05)$, in order to know further the difference, the analysis was continued by using the Least Significant Difference (LSD) test illustrates on table 2 .

Table 2 shows that there is significant difference in every sample group except control group meaning LSD test on table 2 shows significant difference among every immersing group in a period of 30, 60, 90 days in other words that the increase of immersion period in extract solution of Coleus amboinicus, Lour will decrease infl the transverse strength of acrylic resin plate.

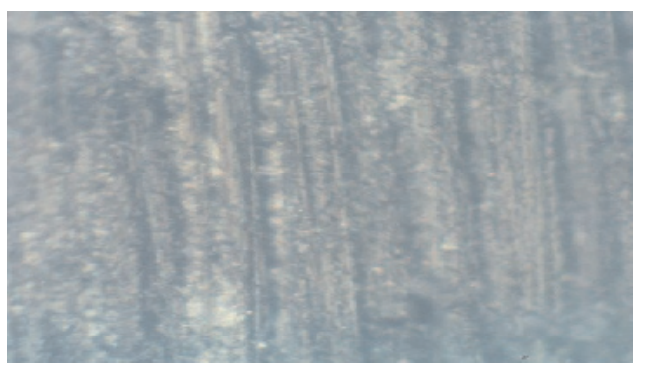

Figure 1. The surface structure of acrylic resin plate immersed in aquadest for 90 days (light microscope, magnified $100 \times)$.

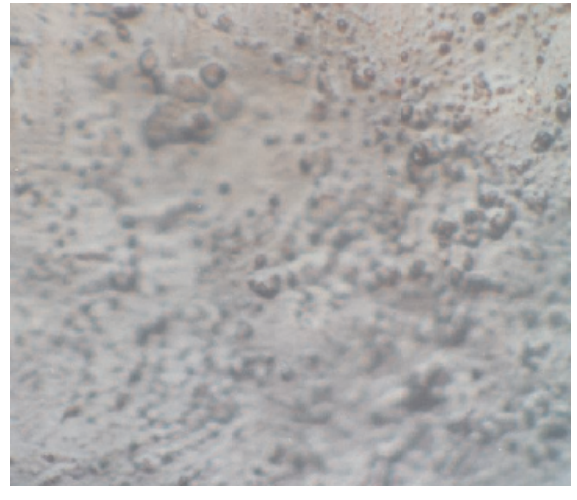

Figure 2. The surface structure of acrylic resin plate immersed in extract solution of Coleus amboinicus, Lour in 15\% concentration for 90 days (light microscope magnified $100 \times)$.

\section{DISCUSSION}

The result of the study showed that mean of transverse strength of acrylic resin immersed in extract solution of Coleus amboinicus, Lour for 30, 60, 90 days. Decreased of the transverse strength of acrylic resin (Table 1). One-Way ANOVA statistical analysis was used and continued by LSD test, the result showed of the longer the immersion duration is, the transverse strength of acrylic resin will significantly decreases. The above outcome might be caused by extract 
of Coleus amboinicus, Lour through chromatography thin layer test, consist of phenol $5.15 \%$ and cineole content in the extract solution of Coleus amboinicus, Lour would influence the transverse strength of acrylic resin. Acrylic resin is polymer in the form of long polyester which consists of repeated methyl methacrylate with low polarity. ${ }^{1}$ Meanwhile phenol is acid in nature with high polarity. In acid condition would be hydrolyzed in case the hydrolysis occurs, polymer will experience degradation and as a result it will probably decrease the transverse strength. Degradation process on structural surface of acrylic resin could be seen on figure 1 and 2 supported by previous researchers. Shen et al. ${ }^{17}$ suggested that the transverse strength dependend on the alteration of morphological surface in which it is strongly influenced by the duration of immersion and the type of disinfectant.

The polyphenol group is responsible for the cause of crazing to polymer. ${ }^{23}$ The main character of acrylic resin is to absorb liquid, therefore, phenol in extract solution will be absorbed into acrylic resin, so that crazing will occur not only in the surface but also will continue to penetrate into acrylic resin plate and finally it would contribute to the decrease of transverse strength. Modern Plastic Encyclopedia ${ }^{17}$ also supported that pure phenol in $5 \%$ concentration would destroy structural surface of acrylic resin. Othmer ${ }^{24}$ also proved that chemical resistant of acrylic resin could be influenced by phenol.

In this study the duration of acrylic resin plate immersion was $30,60,90$ days. It is identical to the duration of acrylic resin denture use for 1, 2, 3 years, if it is 2 hours/day; for 2, 4, 6 years it was immersed in one hour/day immersion duration. Additional duration of immersion shows the significant of transverse strength.

Anderson $^{25}$ reported that due to phenol absorption, acrylic resin molecular bind will be easily broken and eventually the bind among the molecules will be cut off resulting in the decrease of transverse strength. Based on the report acrylic resin immersion for 30, 60, 90 days might have weakened molecular bind and decreased transverse.

The lowest mean transverse strength in $72.70 \mathrm{Mpa}$ originated from acrylic resin plate immersed in extract solution of Coleus amboinicus, Lour with $15 \%$ concentration in 90 days. The transverse strength is still above the recommended value as minimal acceptable transverse strength for acrylic resin denture base that is not allowed to be less than $55 \mathrm{~N} / \mathrm{mm}^{2}$ or $66.04 \mathrm{Mpa} .{ }^{18}$ This was due to the use of cross linked type of heat cured acrylic utilized in this study.

According to ADA No.12, ${ }^{21}$ the cross linked type of neat cured acrylic resin consists of cross linked material in the monomer liquid with $1-2 \%$. Adding this material will make the possibility of the connection between two long polymer molecules, so that it create a stronger, harder and more resistant to scratch, crack and to bear the action of solution. A study by Asad et al. ${ }^{18}$ reported that the decrease of transverse strength occurs in heat cured acrylic resin either cross linked or non cross linked after immersion in disinfectant solution with alcohol base material for 7 days, however transverse strength of acrylic resin for non cross linked is higher than cross linked.

This study is a preliminary study, because the extract processing is more accurate and measurable. Extract material availability is more difficult to obtain, is it is, medicinal herbs processing alternatives is required in order to allow the public easier to utilize it. Based on a study, medicinal herbs processing by infusum technique is apparently better than boiling. The infusum advantages, besides of easier to make and more socialized, it is cheaper because it does not need special treatment and sophisticated equipments as compared to extract. ${ }^{26}$

The outcome of this experimental laboratory study observing transverse strength of acrylic resin immersed in extract solution of Coleus amboinicus, Lour $15 \%$ concentration, it can be concluded that the longer duration of immersion 30, 60, 90 days will cause the decrease of transverse strength of acrylic resin plate. After 90 days duration of immersion the decrease of immersion strength still above the recommended standard transverse strength.

It is suggested that extract solution of Coleus amboinicus, Lour can be used as an alternative cleansing solution for acrylic resin denture and also, it is necessary to conduct further study on the color alteration of acrylic resin after immersion in extract solution of Coleus amboinicus, Lour considering color alteration will influence denture esthetic.

\section{REFERENCES}

1. Combe EC. Notes on dental materials. $6^{\text {th }}$ ed. Edinburg: Churchill Livingstone; 1992. p. 79-120.

2. Anusavice KJ. Phillips' science of dental materials. $11^{\text {th }}$ ed. USA: Saunders; 2003. p. 89-90, 144-6, 723-4, 726-7, 733, 741-4.

3. Edgerton M, Levine MJ. Characterization of acquired denture pellicle from healthy and stomatitis patients. J Prosthet Dent 1992; 68: 683-91.

4. Abelson DG. Denture plaque and denture cleansers. J Prosthet Dent 1981; 45: 376-9.

5. Soenartyo H. Prevalensi Candida albicans rongga mulut orang dewasa serta hubungannya dengan faktor-faktor lokal dan sistemik. Disertation. Surabaya: Universitas Airlangga; 1987. p. 113-4.

6. Elizabeth M. Prevalensi Candida species di daerah tissue surface dari basis gigi tiruan penuh rahang atas. Rimbawan1996; 1b: 1217-26.

7. Radford DR, Challacombe SJ, Walter JD. Denture plaque and adherence of Candida albicans to denture base materials in vivo and in vitro. Crit Rev Oral Biol Med 1999; 10:99-110.

8. Devenport JC. The oral distribution of Candida in denture stomatitis. Brit Dent J 1970; 129:151-6.

9. Jorgensen BE. Material and method for cleaning dentures. J Prosthet Dent 1979; 42:619-22.

10. Nikawa H, Hamada T. Efficacy of commercial denture cleansers. Dent J 1998; 31:77-82.

11. Wijayakusuma H, Dalimartha S, Wirian AG. Tanaman obat berkhasiat Indonesia. Jilid IV. Edisi 1. Jakarta: Pustaka Kartini; 1996. p. $38-41$.

12. Heyne K. Tumbuhan berguna Indonesia. Jilid III. Jakarta: Badan Litbang Kehutanan. Yayasan Sarana Wana Jaya; 1987. p. 1698

13. Rianti D. Efektivitas lama perendaman resin akrilik dalam ekstrak 
daun Coleus amboinicus, Lour terhadap keberadaan Candida albicans. Majalah Kedokteran Gigi Surabaya 2003; 46(4):129-33.

14. Hammerschmidt FJ, Clark AM, Soliman FM, El-Kashoury ES, Kawy MM, Fishawy AM. Chemical composition and antimicrobial activity of essential oil of Jasonia Candicans and Jasonia Montana. Planta Med 1993; 59:68-70.

15. Rahardjo MB. Perbedaan daya antibakteri Allium Sativum Linn dan Kaempferia Galanga terhadap Streptococcus Mutans dan bermacammacam bakteri yang berasal dari saluran akar gigi gangraena pulpae. Thesis. Surabaya: Universitas Airlangga; 1993. p. 13.

16. Windholz M. The Merck index. $11^{\text {st }}$ ed. USA: Merck \& Co., Inc; 1989. p. 34-5.

17. Shen C, Javid NS, Colaizzi FA. The effect of glutaraldehyde base disinfectants on denture base resins. J Prosthet Dent 1989; 61:583-9.

18. Asad T, Watkinson AC, Huggett R. The Effect of disinfection procedures on flexural properties of denture base acrylic resins. J Prosthet Dent 1992; 68:191-5.

19. Dep Kes RI. Farmakope Indonesia. Edisi 3. Jakarta: Dep Kes RI; 1979. p. 12-13

20. Gy Szabo, Stafford GD, Huggett R. Some mechanical properties of denture base polymers treated with an ultraviolet light activated coating material. J Dent 1987; 15:261-65.

21. American Dental Association (ADA). Guide to dental materials and devices. $7^{\text {th }}$ ed. Chicago: American Dental Dental Association; 1974. p. 97-102, 203-8.

22. Beyli MS, Fraunhofer JA. Repaired of fracture acrylic resin. J Prosthet Dent 1980; 44:497-503.

23. Craig RG, Powers JM. Restorative dental materials. $6^{\text {th }}$ ed. London: Mosby Co; 2002. p. 135-40.

24. Othmer K. Encyclopedia of Chemical Technology. $3^{\text {rd }}$ ed. New York: New York Wiley Interscience Publication. John Wiley \& Son; 1982. p. 382.

25. Anderson JN. Aplied dental materials. $5^{\text {th }}$ ed. Oxford Blackwell Scientific Publication; 1976. p. 245-84.

26. Eha D. Khasiat obat kumur infusa daun Kacapiring terhadap perubahan mikroorganisme rongga mulut pemakai gigi tiruan lepasan. Majalah Ilmiah Kedokteran Gigi Fakultas Kedokteran Gigi Universitas Trisakti 1999; Edisi khusus FORIL VI: 497-501. 